„TURYZM”, t. 9, z. 2, 1999

Robert Wiluś

PROGRAM ZAJECĆ DYDAKTYCZNYCH Z PRZEDMIOTU „GEOGRAFIA TURYSTYCZNA POLSKI” NA STUDIACH Z GEOGRAFII TURYZMU I HOTELARSTWA NA UŁ

LE PROGRAMME DES ACTIVITÉS DIDACTIQUES AU SUJET „GÉOGRAPHIE TOURISTIQUE DE LA POLOGNE” AUX ÉTUDES DE LA GÉOGRAPHIE DU TOURISME ET DE L'HÔTELLERIE À L'UNIVERSITÉ DE ŁÓDŹ

\title{
THE CURRICULUM OF THE 'TOURIST GEOGRAPHY OF
} POLAND' SUBJECT AT THE GEOGRAPHY OF TOURISM AND HOTEL MANAGEMENT STUDIES AT THE UNIVERSITY OF ŁÓDŹ

Przedmiot „geografia turystyczna Polski” realizowany jest na trzecim roku studiów geograficznych na specjalizacji z geografii turyzmu i hotelarstwa podczas 20 godz. wykładu i z takiej samej liczby godzin ćwiczeń; zajęcia są obowiązkowe. Geografia turystyczna Polski zajmuje się walorami turystycznymi, zagospodarowaniem turystycznym, a także ruchem turystycznym w kraju. Jednym $\mathrm{z}$ najważniejszych celów nauczania tego przedmiotu jest przekazanie w miarę szerokiej i wszechstronnej wiedzy o atrakcyjności Polski, jej walorów turystycznych i ich przydatności dla rozwoju różnych form współczesnej turystyki. Pozostałe aspekty związane z zagospodarowaniem i ruchem turystycznym zostały w programie przedmiotu praktycznie pominięte, gdyż są one szeroko omawiane na innych zajęciach realizowanych na studiach na specjalności z geografii turyzmu i hotelarstwa ${ }^{1}$. Pomimo tego, zakres przedmiotowy tej wiedzy jest bardzo szeroki. Wiedza ta jest mocno powiązana $z$ innymi dziedzinami geograficznymi, zarówno z zakresu geografii społeczno-ekonomicznej, jak i fi-

1 Przedmioty: „ruch turystyczny”- 20 godz. konwersatorium I rok, „zagospodarowanie turystyczne" -20 godz. II rok, ,podstawy geografii turyzmu" -20 godz. I rok. 
zycznej, a także nie geograficznymi - historią, etnografia, archeologia, architektura, historią sztuki, przyrodą itp. Poznanie walorów turystycznych Polski w tak szerokim zakresie prowadzi do pełnego zrozumienie ich istoty i znaczenia dla rozwoju turystyki.

Bardzo ważnym celem przedmiotu jest wskazanie na możliwości wykorzystania zdobytej wiedzy z geografii turystycznej Polski w przyszłej działalności zawodowej związanej z turystyka, szczególnie przy tworzeniu nowych, oryginalnych i zarazem konkurencyjnych produktów turystycznych odpowiadających aktualnym trendom $w$ turystyce. Przydatność tej wiedzy w praktyce wiąże się $\mathrm{z}$ umiejętnością właściwej oceny rangi walorów turystycznych, co wpływa na tworzenie odpowiednich ofert turystycznych poprzez właściwy wybór walorów. Kierując się zasadą, że największe znaczenie we współczesnej turystyce ma człowiek $^{2}$, podczas zajęć podkreśla się także praktyczną przydatność tej wiedzy polegająca na umiejętnym wynajdywaniu i „dopasowaniu” walorów turystycznych do różnorodnych potrzeb turystów podróżujących po Polsce. Zwraca się tutaj uwagę na walory, które stale decydują o atrakcyjności turystycznej Polski, jak i te, których atrakcyjność zależy od coraz bardziej różnorodnych i zmieniajacych się potrzeb i gustów współczesnych turystów. Tego typu umiejętności ujawniają się $\mathrm{w}$ trakcie podejmowania decyzji związanych zarówno z organizacją różnego rodzaju imprez turystycznych (opracowanie programu), jak i z ich prowadzeniem (pilotaż i przewodnictwo turystyczne). Wiedza z zakresu geografii turystycznej Polski przydatna jest także w działalności związanej z promocją turystyczną regionów, całego kraju, oraz zarządzaniem turystyką na szczeblu lokalnym, regionalnym i centralnym.

Wiedza o walorach turystycznych, jako jednym z najważniejszych elementów potencjału turystycznego Polski, przekazywana jest w ujęciu przestrzennym (regiony turystyczne Polski) i problemowym (wybrane walory turystyczne Polski i związane z nimi formy turystyki). Ujęcie regionalne prezentowane jest w trakcie wykładów. Po omówieniu podstawowych pojęć, takich jak „obszar turystyczny”, ,region turystyczny”, ,miejscowość turystyczna”, „atrakcyjność turystyczna”, "potencjał turystyczny", prezentowane i omawiane są dotychczasowe regionalizacje turystyczne Polski w ujęciu historycznym, genetycznym (stosowane kryteria wyznaczania regionów turystycznych) i przestrzennym (porównanie rozmieszczenia regionów turystycznych do krain geograficznych i historycznych Polski). Kolejne wykłady dotyczą już prezentacji regionów i miejscowości turystycznych poszczególnych stref krajobrazowych Polski strefy nadmorskiej, pojeziernej, nizinnej, wyżynnej i górskiej. Treści przekazywane w trakcie wykładów regionalnych dotyczą najistotniejszych i aktualnych problemów związanych z rozwojem turystyki w danej strefie krajobrazowej,

$2 \mathrm{~W}$ krajach wysoko rozwiniętej gospodarki turystycznej przemysł turystyczny jest nazywany nawet people business. 
oceny atrakcyjności potencjału turystycznego tych stref pod kątem przydatności dla różnego rodzaju form turystyki, wydzielenia regionów turystycznych w poszczególnych strefach, omówienia najważniejszych walorów turystycznych i wyodrębnienia stref funkcjonalnych w zależności od rodzaju funkcji turystycznej w danym regionie oraz określenia znaczenia regionów turystycznych w turystyce krajowej i międzynarodowej.

Głównym celem ćwiczeń jest pokazanie praktycznej przydatności i możliwości wykorzystania szerokiej wiedzy o walorach turystycznych Polski. Każde ćwiczenie wykonywane jest przez studentów indywidualnie, a następnie prezentowane w formie referatu lub przygotowywane pisemnie. Ćwiczenia rozpoczynają się od analizy atrakcyjności turystycznej środowiska naturalnego Polski w aspekcie rozwoju różnych form turystyki. Analiza dotyczy wybranych przez studentów krain geograficznych. W analizie tej należy:

- ocenić atrakcyjność turystyczną poszczególnych elementów środowiska wybranej krainy geograficznej Polski (rzeźby, wód, szaty roślinnej, klimatu),

- podkreślić, który z analizowanych elementów środowiska naturalnego najbardziej decyduje o atrakcyjności turystycznej wybranej krainy geograficznej Polski,

- określić, na ile analizowana kraina geograficzna wyróżnia się pod względem atrakcyjności turystycznej środowiska naturalnego od innych krain (jaka jest ranga danej krainy pod względem atrakcyjności turystycznej),

- dla jakich form turystyki jakie elementy środowiska naturalnego są atrakcyjne turystycznie,

- określić zróżnicowanie przestrzenne atrakcyjności turystycznej w obrębie danej krainy (występowanie obszarów chronionych).

Kolejne ćwiczenia dotyczą oceny atrakcyjności walorów antropogenicznych Polski. Celem ich jest zwrócenie uwagi na zróżnicowanie ilościowe i jakościowe tych walorów, rozmieszczenie najważniejszych obiektów zabytkowych, określenie ich rangi w skali krajowej i międzynarodowej. Ćwiczenie obejmuje swoim zakresem $\mathrm{m}$. in. obiekty zabytkowe wpisane na listę światowego dziedzictwa kulturalnego i naturalnego UNESCO i pomników historii. Aby zapoznać się szczegółowo z wiedzą dotyczącą zabytków z listy UNESCO i pomników historii, studenci dokonują klasyfikacji tych obiektów wg wymyślonych i nazwanych przez siebie co najmniej pięciu kryteriów, a następnie planują trasę jednej wycieczki po Polsce, której celem jest poznanie minimum jednego zabytku $\mathrm{z}$ listy UNESCO oraz trzech pomników historii. Druga część ćwiczenia związanego z poznawaniem walorów antropogenicznych Polski dotyczy zabytków architektury i urbanistyki. Wiedza zdobywana podczas tego ćwiczenia wiąże się ze znajomością stylów architektonicznych. Ćwiczenie kończy się opracowaniem tabeli, w której w porządku chronologicznym (od najstarszego okresu przedromańskiego, przez romanizm, gotyk, renesans/manieryzm, barok/rokoko, klasycyzm, style XIX w. po secesję) wymienia się pięć reprezentatywnych 
obiektów dla danej epoki, określa się ich położenie oraz planuje jedną przykładową trasę związaną z poznawaniem zabytków architektury i urbanistyki dla każdego stylu.

Następne ćwiczenie związane jest ze szlakami turystycznymi, które przebiegają przez Polskę - krajowymi i międzynarodowymi. Celem ćwiczenia jest przede wszystkim podkreślenie znaczenia szlaków turystycznych dla rozwoju współczesnej turystyki. Poza znajomością najważniejszych i najbardziej znanych szlaków, takich jak kopernikowski, piastowski, Orlich Gniazd, zamków krzyżackich, cysterski, Orłowicza, hanzeatycki, bursztynowy, drewnianej architektury sakralnej itp., studenci przygotowują i opracowują własny szlak turystyczny związany z wybranym przez siebie walorem (przyrodniczym lub antropogenicznym), załączając do opisu szlaku także jego mapę.

Kolejne ćwiczenia dotyczą poznawania wybranych atrakcji turystycznych Polski od strony ważniejszych i specyficznych form turystyki rozwijających się w kraju. W tym celu wybrane zostały dwie formy turystyki - turystyka sentymentalna i religijna. Podczas ćwiczeń przeprowadzana jest dyskusja, która dotyczy genezy i oceny zasobów turystycznych Polski dla rozwoju obu wybranych form turystyki. Po dyskusji wykonywane są indywidualne ćwiczenia, które w przypadku turystyki sentymentalnej dotyczą analizy rozmieszczenia walorów związanych z turystyką żydowską w Polsce ${ }^{3}$, a w przypadku turystyki religijnej - zaprojektowania imprezy turystycznej, której celem jest poznanie wybranych obiektów kultu religijnego w Polsce.

Ostatnie zajęcia poświęcone są zagadnieniom atrakcyjności turystycznej Polski dla turystyki przyjazdowej. W trakcie zajęć studenci przygotowują na podstawie wcześniej dostarczonych materiałów propozycje różnych imprez turystycznych na terenie kraju, których program jest odpowiedni do potrzeb turystów zagranicznych odwiedzających Polskę. Rynki zagraniczne, skąd pochodzi większość turystów odwiedzających Polskę, zostały podzielone na kategorie wg ich znaczenia w turystyce przyjazdowej - od najważniejszych (np. rynek USA, Kanady, Francji, Niemiec, Wielkiej Brytanii, krajów Beneluxu, Skandynawii, Izraela, Włoch, Rosji, Ukrainy, Białorusi, Litwy), poprzez rynki mniej znaczące (np. rynek Ameryki Południowej - Brazylia, Argentyna, Chile, Azji - Japonia) i perspektywiczne (np. rynek Korei Południowej). Informacje zawarte w materiałach dostarczonych studentom dotyczą generalnie najważniejszych celów wyjazdów turystycznych poszczególnych nacji, najbardziej popularnych form spędzania przez nich czasu wolnego oraz ważniejszych potrzeb zaspokajanych w trakcie wyjazdów turystycznych.

Oceniając literaturę do przedmiotu ,geografia turystyczna Polski” należy stwierdzić, że brak jest, jak dotychczas, jednego podręcznika, który prezentowałby zagadnienia dotyczące atrakcyjności turystycznej Polski kompleksowo

${ }^{3}$ Do wykonania ćwiczenia studenci otrzymują mapę rozmieszczenia judaików w Polsce. 
i jednocześnie wyjaśniałby związki pomiędzy występującymi na terenie Polski walorami turystycznymi a środowiskiem, historią itp., co pozwalałoby na lepsze zrozumienie i opanowanie niezbędnego materiału. Przyczyną tego jest na pewno duża trudność w napisaniu takiego podręcznika związana z szerokim zakresem przedmiotowym wiedzy z geografii turystycznej Polski. Treść wielu podręczników, które dotyczą generalnie geografii turystyki Polski, nastawiona jest bardziej na opis faktów związanych z walorami turystycznymi, zagospodarowaniem turystycznym, regionami turystycznymi itp. Jedynym dostępnym obecnie podręcznikiem akademickim tego typu jest trzecie wydanie Geografii turystyki Polski autorstwa Teofila Lijewskiego, Bogdana Mikułowskiego i Jerzego Wyrzykowskiego. W porównaniu z pozostałymi pozycjami, które ukazały się dość dawno (B a j c a r 1969, B a r 1974, B a r, D o 1 ińs k i 1975, C h u d o b a, D z i e rża nowski 1972), jak i nowszymi (K r u c z e k, S a c h a 1994), podręcznik ten prezentuje najwyższy poziom merytoryczny. Nie mniej studiowanie jego treści stwarza pewne trudności związane z koniecznością poznania bardzo dużej liczby różnego rodzaju faktów dotyczących atrakcyjności turystycznej Polski. Bez posiadania podstaw wiedzy ogólnogeograficznej, historycznej i z innych dziedzin, zrozumienie istoty i znaczenia różnorodnych walorów turystycznych Polski dla rozwoju turystyki jest praktycznie niemożliwe. Istniejącą lukę w niewielkim stopniu wypełnia X tom Encyklopedii geograficznej świata dotyczący Polski (1997). W zwięzły i zarazem bardzo ciekawy sposób przedstawiono w nim zagadnienia dotyczące geografii, historii, a także turystyki Polski. Książka jest bardzo bogato ilustrowana licznymi kolorowymi fotografiami, mapami i rysunkami, które ułatwiają przyswojenie wiedzy ogólnogeograficznej o Polsce. Podobną funkcję spełnia także podręcznik A. Dylikowej Krainy geograficzne Polski, w którym - w ramach geograficznej charakterystyki poszczególnych krain - można odnaleźć interesująco sporządzony opis piękna krajobrazu. Bardzo ważnym i wykorzystywanym na zajęciach z geografii turystycznej Polski źródłem wiedzy są liczne mapy turystyczne, a zwłaszcza tematyczne (np. mapy zamków, ochrony przyrody, ośrodków kultu religijnego itp.) i te, które dotyczą regionów turystycznych. Dużą rolę w zdobywaniu wiedzy z geografii turystycznej Polski odgrywają wszelkiego rodzaju wydawnictwa albumowe, których jest obecnie bardzo dużo i trudno wyróżniać tutaj jakiś konkretny przykład. Wyjątkiem może być seria wydawnicza dotycząca zabytków $\mathrm{z}$ listy światowego dziedzictwa kulturowego i naturalnego UNESCO. W tomie dotyczącym Europy północnej i środkowej zamieszczono opis tego typu obiektów znajdujących się na terenie Polski wraz z bardzo dobrymi fotografiami. Istnieje także spora grupa wydawnictw przewodnikowych, folderowych po Polsce, których nie sposób pominąc, ale trudno polecić jako literaturę obowiązkową ze względu na ich liczbę i formę opracowania. Tego typu źródła wiedzy stanowią bardzo dobrą literaturę uzupełniająca, wykorzystywaną zwłaszcza w trakcie ćwiczeń. Podobną zaletę mają wydawnictwa słownikowe. Najważ- 
niejszym opracowaniem jest w tym zakresie Slownik geograficzno-krajoznawczy Polski pod redakcją Ireny Mileskiej. Ponadto warto tu wymienić także leksykon Miejsca święte Rzeczypospolitej pod redakcją Antoniego Jackowskiego.

Przedmiot „geografia turystyczna Polski” kończy się egzaminem ustnym. Podczas egzaminu sprawdzana jest przede wszystkim umiejętność posługiwania się zdobyta wiedzą nie tylko poprzez wymienienie, wskazanie na mapie i opisanie atrakcji występujących $w$ różnych regionach turystycznych, ale także przez określenie rangi poszczególnych walorów turystycznych oraz zależności, jakie występują pomiędzy walorami turystycznymi a środowiskiem geograficznym, historia itp. Dodatkowo w trakcie egzaminu pokazywane sa ilustracje (zdjęcia lub przeźrocza) różnych obiektów turystycznych ${ }^{4} \mathrm{z}$ Polski, które należy rozpoznać, określić ich położenie oraz przedstawić podstawowe informacje np. o stylu, historii, randze obiektu itp.

\section{Program wykladów}

1. Cele, program wykładu, forma egzaminu, literatura. Geografia turystyczna Polski - główne zadania badawcze. Omówienie istniejących waloryzacji i regionalizacji turystycznych Polski. Podział Polski na regiony turystyczne - porównanie regionalizacji turystycznych z regionami geograficznymi wg A. Dylikowej.

2. Regiony turystyczne nizin nadmorskich (cz. I).

3. Regiony turystyczne nizin nadmorskich (cz. II).

4. Regiony turystyczne Pojezierza Pomorskiego.

5. Regiony turystyczne Pojezierza Mazurskiego.

6. Regiony turystyczne Krainy Wielkich Dolin.

7. Regiony turystyczne starych gór, wyżyn i Niziny Śląskiej (cz. I).

8. Regiony turystyczne starych gór, wyżyn i Niziny Śląskiej (cz. II).

9. Regiony turystyczne Karpat, nizin i kotlin podkarpackich (cz. I).

10. Regiony turystyczne Karpat, nizin i kotlin podkarpackich (cz. II).

\section{Program ćwiczeń}

1. Ćwiczenia organizacyjne. Omówienie celu, zakresu, programu formy zaliczenia ćwiczeń.

2-4. Atrakcyjność turystyczna krajobrazu Polski w aspekcie rozwoju różnych form turystyki - analiza atrakcyjności walorów przyrodniczych krain geograficznych Polski.

5. Zabytki, pomniki historii, obiekty światowego dziedzictwa kulturowego i naturalnego UNESCO w Polsce.

${ }^{4}$ Każdy student rozpoznaje jeden obiekt. 
6. Atrakcyjność turystyczna Polski dla turystyki religijnej.

7. Turystyka sentymentalna do Polski-Niemcy, Żydzi - walory, obszary najbardziej atrakcyjne.

8. Turystyka innych narodowości - popyt na produkty turystyczne Polski turystów z ważniejszych rynków turystycznych na świecie.

9. Szlaki turystyczne w Polsce - rodzaje, ranga.

10. Podsumowanie ćwiczeń.

\section{Literatura do przedmiotu ,geografia turystyczna Polski”}

B a j c a r A., 1969, Regiony turystyczne Polski, „Geografia w Szkole”, z. 3-4.

B a r R., 1974, Geografia walorów turystycznych Polski, WSWF, Gdańsk.

B a r R., D o I i ń s k i A., 1975, Geografia turystyczna Polski, PTE, Kraków.

Chu do b a T., D z i e rża now s k i L., 1972, Geografia turystyczna Polski, PTE, Kraków.

Cudze chwalicie... Geografia turystyczna Polski (poradnik), 1994, Agencja DINO, Warszawa.

D y 1 i k A., 1973, Geografia Polski. Krainy geograficzne, PZWS, Warszawa.

Encyklopedia geograficzna świata, t. X: Polska, 1997, Kraków.

J a c k o w s k i A. (red.), 1999, Miejsca święte Rzeczypospolitej. Leksykon, Znak, Kraków.

K r u c z e k Z., S a c h a S., 1994, Geografia atrakcji turystycznych Polski, Kraków.

L e ś k o R., K l e m e n t o w s k i K., 1979, Rejonizacja turystyczna (uwzględniajaca nowy podziat administracyjny) oraz określenie zasobów turystycznych podstawowych jednostek gospodarki przestrzennej $w$ turystyce, „Biuletyn Informacyjny Instytutu Turystyki”, nr 1.

L i j e w s k i T., M i k uło w s k i B., W y r z y k ow s k i J., 1998, Geografia turystyki Polski, PWE, Warszawa.

L o t z J., S c h m i d t M., V e s e r T., 1997, Skarby kultury i przyrody świata. Europa pólnocna $i$ środkowa, UNESCO - światowe dziedzictwo kulturalne $i$ naturalne, HENTA, Warszawa.

M i I e s k a J. M., 1963, Regiony turystyczne Polski, „Prace Geograficzne IG PAN”, nr 43.

M i I e s k a J. M. (red.), 1998, Stownik geograficzno-krajoznawczy Polski.

Dr Robert Wiluś

Katedra Geografii Miast i Turyzmu

Uniwersytet Łódzki

ul. Kopcińskiego 31

90-142 Łódź
Wpłynęło:

10 grudnia $1999 \mathrm{r}$. 